\title{
Bird populations as sentinels of endocrine disrupting chemicals
}

\author{
Claudio Carere ${ }^{(a)}$, David Costantini( ${ }^{(b)}$, Alberto Sorace ${ }^{(\mathrm{c})}$, \\ Daniela Santucci $^{(\mathrm{d})}$ and Enrico Alleva ${ }^{(\mathrm{d})}$ \\ (a) Dipartimento di Scienze Ambientali, Università della Tuscia, Viterbo, Italy \\ ${ }^{(b)}$ Division of Ecology and Evolutionary Biology, Faculty of Biomedical and Life Sciences, \\ University of Glasgow, Glasgow, United Kingdom \\ (c) Stazione Romana Osservazione e Protezione Uccelli, Rome, Italy \\ (d) Dipartimento di Biologia Cellulare e Neuroscienze, Istituto Superiore di Sanità, Rome, Italy
}

\begin{abstract}
Summary. Exposure to endocrine disrupting chemicals (EDCs) is a widespread phenomenon in nature. Although the mechanisms of action of EDCs are actively studied, the consequences of endocrine disruption (ED) at the population level and the adaptations evolved to cope with chronic EDC exposure have been overlooked. Birds probably represent the animal taxon most successfully adapted to synanthropic life. Hence, birds share with humans a similar pattern of exposure to xenobiotics. In this article, we review case studies on patterns of behaviour that deviate from the expectation in bird species exposed to EDCs. We provide behavioural and ecological parameters to be used as endpoints of ED; methodological requirements and caveats based on species-specific life-history traits, behavioural repertoires, developmental styles, and possibility of captive breeding; a list of species that could be used as sentinels to assess the quality of man-made environment.
\end{abstract}

Key words: endocrine disruptors, birds, sentinel population, behaviour, ecology, ecotoxicology.

Riassunto (Utilizzo di popolazioni di uccelli come sentinelle di interferenti endocrini). L'esposizione agli interferenti endocrini (IE) da parte di contaminanti chimici è un fenomeno diffuso in natura. I meccanismi d'azione degli IE sono stati ampiamente studiati, tuttavia è stata prestata poca attenzione alle conseguenze della interferenza endocrina a livello di popolazione e agli adattamenti evoluti per fronteggiare l'esposizione cronica agli IE. Gli uccelli probabilmente rappresentano il taxon animale più adattato alla vita sinantropica. Per questo motivo, gli uccelli condividono con gli esseri umani una simile esposizione agli xenobiotici. In questo articolo viene presentata una rassegna degli studi sui profili comportamentali che deviano da quelli attesi in specie e popolazioni di uccelli esposte agli IE. In particolare, vengono suggeriti parametri comportamentali ed ecologici da utilizzare come potenziali marcatori di esposizione agli IE; una valutazione critica dei metodi e dei problemi legati alle differenze specie-specifiche in caratteristiche eco-etologiche, profili comportamentali, tipologie di sviluppo e possibilità di allevamento in cattività; una lista di specie potenzialmente utili come sentinelle per la valutazione della qualità dell'ambiente antropizzato.

Parole chiave: interferenti endocrini, uccelli, popolazioni sentinella, ecologia, comportamento, ecotossicologia.

\section{INTRODUCTION}

Many field studies have been describing a high variation in behavioural and related life history traits in wild bird populations, such as extra-pair paternity, sex ratio, clutch size, parental care [1-3]. On the one side, behavioural ecologists are inclined to interpret these findings as a result of functional adaptations. On the other side, several studies have been showing that many animal populations are exposed to endocrine disrupting chemicals (EDCs) [4-19]. The possibility that some of the described variation stems to some extent by environmental contamination, in particular EDCs is therefore an actual explanation, which is explored in this paper, together with the challenge to test it.
Since the classical work of Kettlewell [20] on the industrial melanism in Biston betularia, the interest in the interactions between pollutants and organism adaptation in a changing environment has grownup extensively. Many studies examining changes in natural animal populations associated with pollution raised concerns on whether or not behavioural changes caused by pollution are a serious threat for the population viability [21-24].

Hormones represent the interface between internal and external stimuli [25]. They regulate homeostasis mechanisms and metabolism and affect sexual and behavioural characteristics. Bird studies on hormones are useful for understanding the variation in behav- 


$\begin{aligned} & \text { Table } 1 \mid \text { Review of the main endocrine disrupting compounds of interest. We focus on the following xenobiotics because they } \\ & \text { are the most widespread, they all have been shown to have estrogenic activity, and they have been largely found in birds }\end{aligned}$
$\begin{array}{ll}\text { Compound } & \text { Short notes }\end{array}$
$\begin{array}{ll}\text { Polychlorinated biphenyls (PCBs) } \\ \text { and dioxins (PCDDs) }\end{array}$
$\begin{aligned} & \text { PCBs are very persistent in the environment, fat soluble, tending to accumulate in organisms } \\ & \text { estrogenic, mimicking estradiol [75], although some congeners may be anti-estrogenic [76]. }\end{aligned}$
$\begin{aligned} & \text { Include lindane, atrazine, DDT, DDE, dieldrin, chlordecon, endosulfan, methoxyclor and toxaphene } \\ & \text { Organochlorine pesticides }\end{aligned}$
$\begin{aligned} & \text { For example, industrial detergents. Include all estrogenic compounds. } \\ & \text { Phylphenols }\end{aligned}$
$\begin{aligned} & \text { Widely used as plasticisers, they are also testicular toxins and can imitate estradiol. } \\ & \text { It causes adrenal dysfunction and suppression of reproduction [29]. }\end{aligned}$
$\begin{aligned} & \text { The food antioxidant butylated hydroxyanisole (BHA), the fungicide vinclozolin and plant } \\ & \text { phytoestrogens. }\end{aligned}$

iour or physiology [26-28]. Endocrine disruption (ED) due to endocrine disrupting chemicals (EDCs) that mimic the action of hormones (Table 1) can cause altered patterns of behaviour. This is a widespread phenomenon already described decades ago [29]. ED has been receiving much attention in the fields of toxicology and environmental health. On the other hand, however, ED has received scanty attention from behavioural biologists and animal ecologists (but see [24, 30]. Although the various effects of these compounds are actively studied in their mechanisms of action, the functional consequences of EDCs at the population level, the actual endpoints when using wildlife sentinels, and how adaptations may evolve in natural populations with chronic exposure to EDCs have been overlooked.

Many bird species are long-lived and feed at the top of the food chain, therefore, they are particularly vulnerable to EDCs [17, 19, 23, 31-36], while there are large differences in sensitivity among species (e.g., dioxin in [37]). Birds show a full range of breeding systems (from monogamy to polyandry) and developmental styles (from altricial to precocial). Further, many species represent successful "commensal type" species, having acquired a successful adaptation and a rapid radiation on co-adaptive use of human by-products. Other species are strictly associated with human settlements, especially during breeding, therefore, sharing with human populations a similar exposure pattern to man-made chemicals. Many bird species have a widespread distribution across latitude and different habitat types. In particular, some of them include populations with extreme synanthropic habits and others inhabiting wild or low contaminated areas. Several common species, which entail these features, such as quails, tits, starlings, gulls, oystercatchers, pigeons and kestrels, can also be housed in captivity under laboratory or semi-natural conditions. Importantly, their behavioural ecology is well known (see references herein).

By focusing on birds, and regardless of the threat to populations per se, we would like to stress that the developmental, behavioural or reproductive chang- es, even if subtle, may be at the same time easier to detect and to compare with the existing baseline values being somehow representative of the level of pollution stress. To do that we need to choose appropriate models (sentinel species and population sharing habitat and exposure to pollutants with human beings) and a number of parameters already used by ethologists and animal ecologists.

Wildlife sentinels may be regarded as those populations that can react to environmental contaminants before the contaminant impacts humans [38]. It is clear that the response to contaminants, based on scientifically supportable observations, should be detected both by observations on wild animals in field situations, as well as by experimental data recorded under more controlled conditions [30, 32, 39]. Both approaches could be useful as for additional weight of evidence in a risk assessment, to provide early warning of situations requiring further study, or to monitor the course of remedial activities [38].

The aims of this contribution are: 1) to provide appropriate endpoints and formulate expectations to assess the effects of EDCs in sentinel avian populations; 2) to provide methodological guidelines to choose the appropriate species or populations; 3 ) to generate hypotheses on the functional consequences of EDCs on the individual behaviour, coping strategies and population dynamics.

\section{BEHAVIOURAL ECO-TOXICOLOGICAL FIELD STUDIES: THE PROS AND CONS}

Behavioural eco-toxicological field studies have been carried out basically in two different ways, both entailing advantages and drawbacks [23, 40]: investigation on EDC effects already occurred [7, 17, 32] or occurring; for that the existing variation is the material to analyse, to disentangle from the "natural" variation and, eventually, to correlate with the level of pollution. The main difficulty of this approach is to demonstrate that the observed change has a causal link with the pollutant(s) of interest. The second approach is the investigation in which the pollutant is added as a part of the study [41-45]. For this latter 
Table 2 | Detecting endocrine disrupting effects at individual and population level. The importance of behaviour

- The behavioural phenotype represents the outcome of integration between non genetic, genetic, biochemical and physiological processes [79].

- Behaviour is highly sensitive to perturbation [80]. A high sensitivity of the endpoint is a crucial requisite for its use in exploring sublethal or subchronic effects.

- Behavioural experiments are usually mild in terms of animal welfare. Some effects of EDCs become apparent only when tested in natural ecological setting, such as social stress [30].

- The tools necessary to evaluate behaviour are relatively inexpensive [24].

approach, it is pivotal to validate that the treatment has being done properly indeed. In such studies, it is basically possible to establish a cause-effect relationship. Technical, procedural and also normative problems abound, though $[17,38]$. It is clear that for a proper assessment both approaches should be used to answer a same question. A conditio sine qua non when choosing target sentinel species or population is that behavioural-physiological-ecological baseline values do exist for them. Ethologists and, more recently, behavioural ecologists have explored most of the traits we are suggesting to use as endpoints in a number of species, populations or contexts (Tables 2-4).

\section{THE PROBLEM}

Two authors [23, 40] outlined the state of the art of behavioural eco-toxicology. Both summarised actual field data and highlighted difficulties emerging in using behavioural field data as an index of pollu- tion-related environmental stress (see Table 3 for a selection of case studies in the field). However, they finalised the analyses in finding short-term adverse effects on behaviour (e.g., abnormal behaviours leading to impairment in reproduction or increase in mortality) and threat for the study population in a conservation biology perspective. This might be the case, yet even the contrary could prove useful when ED does work. Being an indicator of environmental pollution does not necessarily mean that the pollution has adverse effects.

Given the crucial role of the endocrine system for an organism, the picture may be complicated by ED. All effects might be observed at the level of population dynamics after years or decades, e.g., skewed sex ratio, abnormalities in partner preference or decrease in paternal care. Changes of this type may lead to a behavioural response of the individual that could end up in an adaptive, neutral or in a maladaptive response leading to population decline up to extinction.

\section{EXAMPLES OF ENDOCRINE DISRUPTION EFFECTS IN BIRDS AT THE PHYSIOLOGICAL LEVEL}

EDCs may have several consequences for the physiological condition of the individuals. This is of interest because alterations of the physiological homeostasis may cause; 1) behavioural aberrations; and 2) pathologies that may increase mortality rate.

Alterations of the immunocompetence is a pivotal issue because the immune system enables organisms to resist infections. Moreover, several studies suggested that the relationship between life-history decisions and parasitism may be modulated by a

\begin{tabular}{|c|c|c|c|c|c|}
\hline ED Compound & Behaviour/Ecological process & $\begin{array}{c}\text { Field (F)/ } \\
\text { Lab study (L) }\end{array}$ & Two-tailed prediction & Species & Source \\
\hline $\begin{array}{l}\text { PCBs, } \\
\text { organochlorines }\end{array}$ & Parasite invasion & $\mathrm{F}$ & De-forcing the immune system & $\begin{array}{l}\text { Glaucous gull } \\
\text { (Larus hyperboreus) }\end{array}$ & [81] \\
\hline PCBs & $\begin{array}{l}\text { Altered nest building pattern, higher } \\
\text { nest abandonment, supernormal } \\
\text { clutches }\end{array}$ & $\mathrm{F}$ & & $\begin{array}{l}\text { Tree swallow } \\
\text { (Tachycineta bicolor) }\end{array}$ & [69] \\
\hline PCBs & $\begin{array}{l}\text { Altered sub-adult plumage } \\
\text { (reproduction relevant) }\end{array}$ & $\mathrm{F}$ & $\begin{array}{l}\text { Disruption of the endocrine } \\
\text { system resulting in the early } \\
\text { expression of an adult trait }\end{array}$ & $\begin{array}{l}\text { Tree swallow } \\
\text { (Tachycineta bicolor) }\end{array}$ & [52] \\
\hline PCBs & $\begin{array}{l}\text { Altered sexual behaviour (nest } \\
\text { inspections, solicitation of } \\
\text { copulation, food offer to female) }\end{array}$ & L & & $\begin{array}{l}\text { American kestrel } \\
\text { (Falco sparverius) }\end{array}$ & [45] \\
\hline PCBs & $\begin{array}{l}\text { Lower clutch size, hatching } \\
\text { success }\end{array}$ & L & & $\begin{array}{l}\text { American kestrel } \\
\text { (Falco sparverius) }\end{array}$ & [44] \\
\hline $\begin{array}{l}\text { TCDD, PCDDs, } \\
\text { PCFs, PCBs }\end{array}$ & Lower reproductive success & $\mathrm{F}$ & & $\begin{array}{l}\text { Great blue heron } \\
\text { (Ardea herodias) }\end{array}$ & [82] \\
\hline EDSs & Alteration of various behaviours & L & & $\begin{array}{l}\text { Japanese quail } \\
\text { (Coturnix japonica) }\end{array}$ & [43] \\
\hline
\end{tabular}


Table 4 | Potential endocrine disruption chemicals (EDCs) effects and consequences in ecology and behaviour of an altricial bird, the common swift (Apus apus) showing typical biparental care behaviour. It is expected that in such scenario a decrease in contribution of one of the parents due to ED is compensated by the partner, thus masking the effect in the short term. However, the compensating parent may pay the cost in the long term (see text for further explanations)

\begin{tabular}{|c|c|c|}
\hline & NO EDCs effects & EDCs effects \\
\hline Parenting & $\begin{array}{l}\text { Biparental care } \\
(\mathrm{M}=\mathrm{F})\end{array}$ & $\begin{array}{l}\text { Skewed parental } \\
\text { care }(F>M)\end{array}$ \\
\hline Clutch size & Normal & Normal or low \\
\hline Hatching success & Normal & Normal or low \\
\hline Young mortality & Normal & High \\
\hline Second clutches & Yes & No \\
\hline Sex ratio & Normal & Skewed \\
\hline Partner preference & Normal & Skewed \\
\hline Timing of breeding & Normal & Delayed \\
\hline Aggressiveness & Normal & High \\
\hline Nest building behaviour & Normal & Altered \\
\hline
\end{tabular}

trade-off between investment in life-history traits and immune response [46].

Polybrominated diphenil ethers (PBDEs) are additive flame retardants that may cause alterations of the immune system. In captive nestling American kestrels (Falco sparverius), environmentally relevant PBDEs modified the functioning of both the cell-mediated and humoral branches of the immune system, and resulted in structural alterations in the immune organs [47]. The results suggested that the immune system would fail to respond appropriately to pathogens with detrimental consequences for the animal.

EDCs may jeopardize body homeostasis also by dysregulating mechanisms that maintain redox homeostasis causing oxidative stress as a consequence. Oxidative stress is caused when the balance between pro-oxidants and anti-oxidants is unbalanced toward pro-oxidants [48]. Such shift of the cell redox balance toward more oxidant conditions causes oxidative damage, which underlies several degenerative pathologies.

Pesticides are compounds that are used to kill pest species. However, at the same time, these chemicals have caused severe environmental pollution and health hazards. Pesticides may cause oxidative stress, increasing production of free radicals with consequent per-oxidation of tissues and altering the anti-oxidant machinery of the body [49].

Evidence so far indicates that certain EDCs may have detrimental consequences for birds during the development, as well as the adult phase. For example, oxidative stress has been implicated in the $3,3^{\prime}, 4,4^{\prime}, 5-$ pentachlorobiphenil-induced embryo toxicity in the White Leghorn chicken (Gallus domesticus) and the Pekin duck (Anas platyrhynchos) [50]. Common eiders (Somateria mollissima) populations exposed to polycyclic aromatic hydrocarbons and organochlorines had higher levels of DNA damage compared to unexposed populations [51].
Several studies have shown that EDCs may affect the expression of avian coloration, raising concerns on the phenotypic effects of contaminants [52-54]. Evidence on captive American kestrels showed that circulating carotenoids and skin carotenoid coloration were both disrupted in birds exposed to a dietary mixture of a 1:1:1 Aroclor 1254, 1248 and 1260 compared to controls [53]. Given that carotenoidbased coloration does work as signal of phenotypic quality in the mate choice, modulation of both colour and carotenoid concentration by EDCs could have relevant consequences to social behaviour other than health. In addition, avian colouration could prove useful as a bioindicator of contaminant exposure. An example of how this could hold for wild birds comes from great tits Parus major [55]. Great tits derive the carotenoid pigments for their yellow plumage mainly from caterpillars, whose abundance is greatly affected by air pollution. Indeed, both the intensity of yellow colour in nestling plumage and caterpillar abundance increased with increasing distance from a factory complex producing copper, nickel and fertilizers. These findings called attention for potential interferences in the mate choice or in the male-male competition which are both modulated by colour intensity in great tits.

\section{SENTINEL POPULATIONS}

Whether ED consequences are or are not adverse for the target population is difficult to ascertain, but this is not the primary interest in using a population as a sentinel. Of course everybody would be satisfied to show a direct effect on fitness parameters or survival in the target population, but we are positive to state that with chronic, sublethal exposures to EDCs this will rarely be the case. The dynamic of the parameters of a population are the basis of the concept of sentinel. First, the absence of evidence that EDCs affect behaviour in the short term can reflect a lack of appropriate research and/or reliable endpoints rather than the lack of a behavioural effect. Second, we have to assess potential case studies to ascertain what contribution EDCs provide to changes in behaviour or in ecological parameters.

Exposure to EDCs is likely to affect males and females differently, because the functions and concentrations of hormones that regulate reproduction differ greatly between the sexes [56]. Moreover, unlike females, males do not have the opportunity to eliminate part of their contaminant burden through the deposition of contaminants into eggs. For example, in American kestrels (Falco sparverius), the incubation behaviour of PCB-exposed males was more disrupted than that of PCB-exposed females [34]. Such a result was similar to that reported in glaucous gulls (Larus hyperboreus), where the increased incubation costs caused a decrease in nest temperature, which tended to be more pronounced when incubation was being conducted by male rather than female glaucous gulls [36]. 
This scenario is particularly relevant in biparental care species ( $80 \%$ of birds, [57]) because it is likely that a decrease in contribution of one of the parents due to ED is compensated by the other partner. The effect on chick survival will be certainly masked in the short term. However, the compensating parent may pay the cost in the long term, for example, either by reducing second clutches or decreasing its ability to reproduce in the following season, or simply producing smaller clutches or reducing its ability to fledge the same number of offspring [58-59]. As a consequence, demographic effects may lead to higher mortality of one sex and skewed operational sex ratio in the population. Hence, at a certain age, a bias in sex ratio could be observed as an ultimate consequence of EDCs (Table 4).

Another way of compensation could be looking for extra-pair copulation to gain compensation or help in parental care from extra-pair males, a phenomenon largely described in bird species previously supposed to be genetically monogamous and interpreted with adaptive hypotheses [2, 60, 61]. In the absence of extra-pair help, the brood might grow up in a disrupted rearing condition, i.e., reduced amount of male care, with possible consequences on the future socio-sexual behavior, such as in partner preference. Therefore, once an effect on paternal care is expected/observed, it will be necessary to take into account life-history parameters including clutch size, percentage of second clutches, primary and secondary sex ratio, as well as the engagement of females in extra-pair activity or the genetic paternity of the offspring.
What species may be considered as sentinels of EDC effects? In principle, a broad view of the use of sentinels may lead to relevant outcomes of interest. The biology of a given bird species might affect the exposure and/or the behavioural response to EDC pollutants [24, 30, 62-64]. Further, sentinel populations could be exposed to a single chemical, to a complex mixture, or to different media in various locations.

We propose criteria including the following features:

- developmental style (altricial vs precocial)

- breeding style (territorial vs colonial)

- migratory habits (migratory vs resident)

- interaction with man-made landscape (synanthropic vs non synanthropic)

- trophic level (high, intermediate, low)

- possibility to breed in captivity

- knowledge of the species behavioural ecology

We provide examples of candidate species according to such criteria in Table 5.

\section{ATTRIBUTING VARIATION TO ENDOCRINE DISRUPTION. ADVERSE EFFECTS AND INTERFERENCE WITH EVOLUTIONARY FORCES}

The difficulty remains in attributing the changes to the pollutant(s) of interest, but we have to accept that this will always remain in terms of statistical likelihood. For example, a change in clutch size or sex ra-

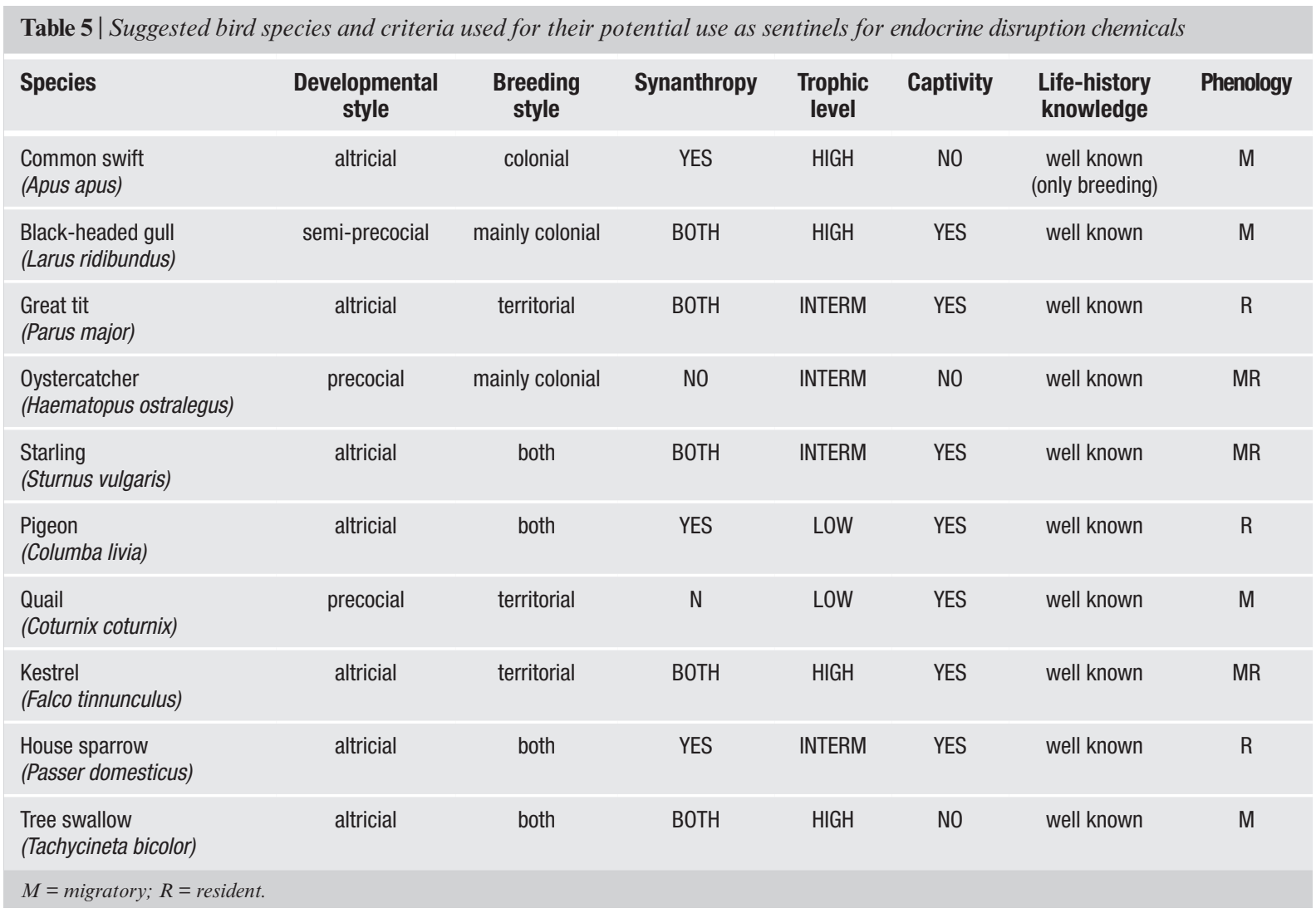


tio in the past 10 years observed in a polluted area and not in a uncontaminated one, or in a gradient of pollution, provided that the pollutant(s) of interest does have an experimentally proved effect on certain crucial behaviours, could be sufficient to consider the population of that species as an important sentinel. Databases on clutch size or sex ratio in many bird species are currently available in most of behavioural biology and ornithology departments. They just need to be explored considering that ED plays a role in the unexplained, sometimes consistent, variation.

Peakall [40] did not properly emphasize that in the large body of literature reviewed (as well as in the more recent one reported in the present paper) behavioural changes due to pollutants have been described. They did not cause any short-term adverse effects. However, this does not mean at all that the populations in which changes are observed cannot be used as sentinels.

To date, this kind of approach has been neglected from the traditional approach of behavioral toxicology. While behavioral toxicologists use animals as "tools" to detect alterations in neural or endocrine processes, they overlook their social and environmental situations, as well as that EDCs may interfere with the evolutionary forces that shaped the biological systems trough a direction that can be predicted. Two experimental reports describing effects of EDCs on behavioural development in rodents adopted this kind of approach in the interpretation of the results $[65,66]$. Such an approach is relevant as, for example, individual differences in sensitivity to environmental chemicals may eventually lead to frequency dependent selection of genes involved in these responses.

Another report, though not specifically concerning EDCs, is worth mentioning [55]. The authors used a well studied, common and resident species, the great tit (Parus major), chose a wild population in a gradient of air pollution instead of comparing polluted and not polluted areas, monitored the abundance of the main food source of the species (i.e., the caterpillars), interpreted the findings (fading of the plumage) both in terms of possible mechanisms (shifting in the diet because of decreased abundance of the "coloured" caterpillars) and in terms of implications of colour change for survival and mate choice. This contribution may shed light on adaptation to environmental pollution gradients, including EDCs pollution.

Also, there is an increasing interest about the effects of EDCs on invertebrate species [67]. However, methodological difficulties in tests with terrestrial invertebrate species (e.g., terrestrial exposure is harder to define than for aquatic invertebrates) have been favouring studies on aquatic ones [68]. Behavioural endpoints in insectivorous birds might emphasize the effect of EDCs across the terrestrial food webs.

A third report is also worth mentioning [69]. In this study, a hormonally controlled behavioural endpoint, nest building, which is important for reproductive success was monitored in wild populations of tree swallows (Tachycineta bicolor); the nest quality in three ar- eas with high, intermediate, and low PCB contamination was compared while controlling for other factors such as for example the female age. The results showed a plausible link between contamination and nest quality and were interpreted in terms of adverse effects on fitness in the contaminated areas.

Heg and van Treuren [61] in a remarkable long-term study showed cooperative polygyny including "lesbian" styles (female-female cooperation, copulations and joint nesting) in oystercatchers (Haematopus ostralegus), a species strictly monogamous, occurring in the Waddenzee (The Netherlands), one of the most polluted areas of Europe. No mention or hypothesis of ED in this population has been done, however, although in a very close population of the same species other researchers had previously found high levels of PCBs (see also [70]).

\section{CONCLUDING REMARKS}

In general, behavioural baselines dealing with parental care patterns and breeding systems are available for a number of species and may be exploited to monitor (via alteration of sex-typical features) the occurrence of endocrine-disrupting agents, representing sensitive functional endpoints of ecotoxicological stress. Behavioural processes represent today a well-known topic dealing with both ecological results and modeling techniques, as well as with toxicological and bio-chemical approaches. Nevertheless, researches including both typically ecological field investigations and wide laboratory approaches are rather lacking up to now. The idea is that behavioural ecotoxicologists had widely explored the limits of the problem (for example, assessment of variation in life history traits and behavioral patterns and correlation of them with EDCs levels both in the field and in the laboratory) and have very good chances now to go insight the core of the problem (for example, starting by predictions of the molecular and physiological effects of EDCs compounds on bird ecology and behaviour, to built-up model approaches in the field of evolutionary ecology). Combining field and laboratory data with typical approaches from evolutionary ecology (manipulation experiments in the field), and keeping them linked with molecular predictions and modeling techniques of population dynamic consequences of EDC pollution could represent the best way of "getting closer" among eco-toxicologists and behavioural ecologists.

\section{Acknowledgments}

We are grateful to Luca Salvati for helpful comments and suggestions on an early draft. Claudio Carere, Daniela Santucci, and Enrico Alleva were supported by the STREP-project "StarFlag" n. 12682 in the NEST-programme of "Tackling complexity in science" of 6th European framework. David Costantini was supported by a postdoctoral NERC research fellowship (NE/G013888/1).

Received on 28 July 2009.

Accepted on 20 November 2009. 


\section{References}

1. Clutton-Brock TH. Sex ratio variation in birds. Ibis 1986; 128:317-29.

2. Møller AP. Male parental care, female reproductive success, and extrapair paternity. Behav Ecol 2000;11:161-8.

3. Jetz W, Sekercioglu CH, Böhning-Gaese K. The worldwide variation in avian clutch size across species and space. PloS Biol 2008;6:2650-7.

4. Ulfstrand S, Södergren A, Raböl J. Effect of PCB on nocturnal activity in caged robins, Erithacus rubecula L. Nature $1971 ; 231: 467-8$.

5. Fry DM. Reproductive effects in birds exposed to pesticides and industrial chemicals. Environ Health Perspect 1995;103:165-71.

6. Fry DM, Toone CK. DDT-induced feminization of gull embryos. Science 1981;213:922-4.

7. Guillette LJJr, Crain DA, Rooney AA, Pickford DB. Organization versus activation: the role of endocrine-disrupting contaminants (EDCs) during embryonic development in wildlife. Environ Health Perspect 1995;103:157-64.

8. Henshel DS, Martin JW, Norstrom R, Whitehead P, Steeves JD, Cheng KM. Morphometric abnormalities in brains of great blue heron hatchlings exposed in the wild to PCDDs. Environ Health Perspect 1995;103:61-6.

9. Janz DM, Bellward GD. In ovo 2,3,7,8-tetrachlorodibenzop-dioxin exposure in three avian species. 1. Effects on thyroid hormones and growth during the perinatal period. Toxicol Appl Pharmacol 1996;139:281-91.

10. Janz DM, Bellward GD. In ovo 2,3,7,8-tetrachlorodibenzo-p-dioxin exposure in three avian species. 2. Effects on estrogen receptor and plasma sex steroid hormones during the perinatal period. Toxicol Appl Pharmacol 1996;139:292-300.

11. Gray LE. Xenoendocrine disrupters: laboratory studies on male reproductive effects. Toxicol Lett 1998;103:331-5.

12. Gray LE, Ostby J, Wolf C, Lambright C, Kelce W. The value of mechanistic studies in laboratory animals for the prediction of reproductive effects in wildlife: Endocrine effects on mammalian sexual differentiation. Environm Toxicol Chem 1998;17:109-18.

13. Tyler CR, Jobling S, Sumpter JP. Endocrine disruption in wildlife: a critical review of the evidence. Crit Rev Toxicol 1998;28:319-61.

14. Van der Kraak G. Observations of endocrine effects in wildlife with evidence of their causation. Pure Appl Chem 1998;70:1785-94

15. Fossi MC, Casini S, Marsili L. Non destructive biomarkers of exposure to disrupting chemicals in endargered species endocrine of wildlife. Chemosphere 1999;39:1273-85.

16. Puopolo M, Santucci D, Chiarotti F, Alleva, E. Behavioural effects of endocrine disrupting chemicals on laboratory rodents: statistical methodologies and an application concerning developmental PCB exposure. Chemosphere 1999;39:1259-71.

17. Crews D, Willingham E, Skipper JK. Endocrine disruptors: present issues, future directions. Quart Rev Biol 2000;75:24360 .

18. Grasman KA, Scanlon PF, Fox GA. Geographic variation in hematological variables in adult and prefledgling herring gulls (Larus argentatus) and possible associations with organochlorine exposure. Arch Environ Contam Toxicol 2000;38:244-53.

19. Vos JG, Dybing E, Greim HA, Ladefoged O, Lambré C, Tarazona JV, Brandt I, Vethaak AD. Health effects of endocrine-disrupting chemicals on wildlife, with special reference to the European situation. Crit Rev Toxicol 2000;30:71-133.

20. Kettlewell HBD. Industrial melanism in Biston betularia. Oxford: Oxford University Press; 1973.

21. LeBlanc GA. Are environmental sentinels signaling? Environ Health Perspect 1995;103:888-90.
22. Dawson A. Mechanisms of endocrine disruption with particular reference to occurrence in avian wildlife: a review. Ecotoxicology 2000;9:59-69.

23. Dell'Omo G. (Ed.). Behavioural ecotoxicology. New York: Wiley \& Sons; 2002.

24. Clotfelter ED, Bell AM, Levering KR. The role of animal behaviour in the study of endocrine-disrupting chemicals. Anim Behav 2004;68:465-76

25. Adkins-Regan E, Weber DN (Ed.). Mechanisms of behaviour. In: Dell'Omo G (Ed.). Behavioural ecotoxicology. New York: Wiley \& Sons; 2002.

26. Konishi M, Emlen ST, Ricklefs RE, Wingfield JC. Contributions of bird studies to biology. Science 1989;246:465-72.

27. Ketterson ED, Nolan V Jr. Hormones and life history: an integrative approach. In: Real LA (Ed.). Behavioral mechanisms in evolutionary ecology. Chicago: Chicago Press; 1994.

28. Hau M. Regulation of male traits by testosterone: implications for the evolution of vertebrate life histories. BioEssays 2007;29:133-44.

29. Rattner BA, Eroschenko VP, Fox GA, Michael Fry D, Gorsline J. Avian endocrine responses to environmental pollutants. $J$ Exp Zool 1984;232:683-9.

30. Zala SM, Penn DJ. Abnormal behaviours induced by chemical pollution: a review of the evidence and new challenges. Animal Behav 2004;68:649-64.

31. Berg C, Halldin K, Fridolfsson AK, Brandt I, Brunstrom B. The avian egg as a test system for endocrine disrupters: effects of diethylstilbestrol and ethynylestradiol on sex organ development. Sci Total Environ 1999;233:57-66.

32. Ottinger MA, Abdelnabi M, Quinn M, Golden N, Wu J, Thompson N. Reproductive consequences of EDCs in birds. What do laboratory effects mean in field species? Neurotoxicol Teratol 2002;24:17-28.

33. Scanes CG, McNabb FMA. Avian models for research in toxicology and endocrine disruption. Avian Poultry Biol Rev 2003; $14: 21-52$

34. Fisher SA, Bortolotti GR, Fernie KJ, Bird DM, Smits JE. Brood patches of American kestrels altered by experimental exposure to PCBs. J Toxicol Environm Health A 2006;69:1603-12.

35. Van den Steen E, Eens M, Covaci A, Dirtu AC, Jaspers VL, Neels H, Pinxten R. An exposure study with polybrominated diphenyl ethers (PBDEs) in female European starlings (Sturnus vulgaris): toxicokinetics and reproductive effects. Environm Poll 2009; 157:430-6.

36. Verboven N, Verreault J, Letcher RJ, Gabrielsen GW, Evans NP. Nest temperature and parental behaviour of Arctic-breeding glaucous gulls exposed to persistent organic pollutants. Anim Behav 2009;77:411-8.

37. Karchner SI, Franks DG, Kennedy SW, Hahn ME. The molecular basis for differential dioxin sensitivity in birds: role of the aryl hydrocarbon receptor. PNAS 2006;103:6252-7.

38. van der Schalie WH, Gardner HSJr, Bantle JA, De Rosa CT, Finch RA, Reif JS, Reuter RH, Backer LC, Burger J, Folmar LC, Stokes WS. Animals as sentinels of human health hazards of environmental chemicals. Environ Health Perspect 1999;107:309-15.

39. Blus LJ, Henny CJ. Field studies on pesticides and birds: unexpected and unique relations. Ecol Applic 1997;7:1125-32.

40. Peakall DB. Disrupted patterns of behavior in natural populations as an index of ecotoxicity. Environ Health Perspect 1996:104:331-5.

41. McArthur ML, Fox GA, Peakall DB, Philogène BJR. Ecological significance of behavioral and hormonal abnormalities in breeding ring doves fed an organochlorine chemical mixture. Arch Environ Contam Toxicol 1983;12:343-53. 
42. Tori GM, Peterle TJ. Effects of PCBs on mourning dove courtship behavior. Bull Environ Contam Toxicol 1983;30:44-9.

43. Ottinger MA, Abdelnabi MA, Henry P, McGary S, Thompson $\mathrm{N}$, Wu JM. Neuroendocrine and behavioral implications of endocrine disrupting chemicals in quail. Horm Behav 2001:40;234-47.

44. Fernie KJ, Smits JE, Bortolotti GR, Bird DM. Reproduction success of American Kestrels exposed to dietary polychlorinated biphenyls. Environ Toxicol Chem 2001;20:776-81.

45. Fisher SA, Bortolotti GR, Fernie KJ, Smits JE, Marchant TA, Drouillard KG, Bird DM. Courtship behavior of captive American kestrels (Falco sparverius) exposed to polychlorinated biphenyls. Arch Environ Cont Toxicol 2001;41:215-20.

46. Norris K, Evans MR. Ecological immunology: life-history tradeoffs and immune defense in birds. Behav Ecol 2000; 11:19-26.

47. Fernie KJ, Mayne G, Shutt JL, Pekarik C, Grasman KA, Letcher RJ, Drouillard K. Evidence of immunomodulation in nestling American kestrels (Falco sparverius) exposed to environmentally relevant PBDEs. Environ Pollut 2005;138:485-93.

48. Finkel T, Holbrook NJ. Oxidants, oxidative stress and the biology of ageing. Nature 2000;408:239-47.

49. Abdollahi M, Ranjbar R, Shadnia S, Nikfar S, Rezaie A. Pesticides and oxidative stress: a review. Med Sci Monit 2004;10:141-7.

50. Jin X, Kennedy SW, Di Muccio T, Moon TW. Role of oxidative stress and antioxidant defense in 3,3',4,4,5-pentachlorobiphenylinduced toxicity and species-differential sensitivity in chicken and duck embryos. Toxic Appl Pharmacol 2001;172:241-8.

51. Matson CW, Franson JC, Hollmén TE, Kilpi M, Hario M, Flint $\mathrm{PL}$, Bickham JW. Evidence of chromosomal damage in Common Eiders (Somateria mollissima) from the Baltic Sea. Marine Pollut Bull 2004;49:1066-71.

52. McCarty JP, Second AL. Possible effects of PCB contamination on female plumage color and reproductive success in Hudson River Tree Swallows. Auk 2000;117:987-95.

53. Bortolotti GR, Fernie KJ, Smits JE. Carotenoid concentration and coloration of American Kestrels (Falco sparverius) disrupted by experimental exposure to PCBs. Funct Ecol 2003;17:651-7.

54. Dauwe T, Eens M. Melanin- and carotenoid-dependent signals of great tits (Parus major) relate differently to metal pollution. Naturwissenschaften 2008;95:969-73.

55. Eeva T, Lehikoinen E, Ronka M. Air pollution fades the plumage of the great tit. Funct Ecol 1998;12:607-12.

56. Farner DS, Wingfield JC. Reproductive endocrinology of birds. Ann Rev Physiol 1980:42;457-72.

57. Lack D. Ecological adaptations for breeding in birds. London: Methuen; 1968.

58. Roff DA. Life history evolution. Sunderland, Massachusetts: Sinauer Associates; 2002

59. Dawson RD, Bortolotti GR. Experimentally prolonging the brood-rearing period reveals sex-specific parental investment strategies in American kestrels (Falco sparverius). Auk 2008;125:889-95.

60. Birkhead TR, Møller AP(Ed.). Sperm competition in birds: evolutionary causes and consequences. London: Academic Press; 1992.

61. Heg D, van Treuren R. Female-female cooperation in polygynous oystercatchers. Nature 1998;391:687-91.

62. Elliott JE, Kennedy SW, Lorenzen A. Comparative toxicity of polychlorinated biphenyls to Japanese quail (Coturnix c. japonica) and American kestrels (Falco sparverius). J Toxicol Environ Health 1997;51:57-75.

63. Blus LJ. Organochlorine pesticides. In: Hoffman DJ, Rattner BA, Burton GA Jr, Carlisle JC (Ed.). Handbook of ecotoxicology. Boca Raton: Lewis Publishers; 2003. p. 313-39.
64. Miniero R, Carere C, De Felip E, Iacovella N, Rodriquez F, Alleva E, Di Domenico A. The use of common swift (Apus apus), an aerial feeder bird, as a bioindicator of persistent organic microcontaminants. Ann Ist Super Sanità 2008;44:187-94.

65. Palanza P, Morellini F, Parmigiani S, vom Saal FS. Prenatal exposure to endocrine disrupting chemicals: effects on behavioral development. Neurosc Biobehav Rev 1999;23:1011-27.

66. Palanza P, Parmigiani S, Liu HF, Vom Saal FS. Prenatal exposure to low doses of the estrogenic chemicals diethylstilbestrol and o,p -DDT alters aggressive behavior of male and female house mice. Pharmacol Biochem Behav 1999;64:665-672.

67. deFur P, Crane M, Ingersoll C, Tattersfield L (Ed.). Endocrine disruption in invertebrates: endocrinology, testing and assessment. Pensacola, USA: SETAC Press.

68. Weltje L, Schulte-Oehlmann U. The seven year itch - progress in research on endocrine disruption in aquatic invertebrates since 1999. Ecotoxicol 2007;16:1-3.

69. McCarty JP, Second AL. Nest building behavior in PCB-contaminated tree swallows. Auk 1999;116:55-63.

70. Everaarts JM, De Buck A, Hillebrand MT, Boon JP. Residues of chlorinated biphenyl congeners and pesticides in brain and liver of the oystercatcher (Haematopus ostralegus) in relation to age, sex and biotransformation capacity. Sci Total Environ 1991;100:483-99.

71. Herbert CE, Shutt JL, Norstrom RJ. Dietary changes cause temporal fluctations in polychlorinated biphenyl levels in Herring Gull eggs from Lake Ontario. Environm Science Technol 1997;31:1012-7.

72. Helander B, Olson A, Bignert A, Asplund L, Litzén K. The role of DDE, PCB, coplanar PCB and eggshell parameters for reproduction in the White-tailed Sea Eagle (Haliaeetus albicilla) in Sweden. Ambio 2002;31:386-403.

73. Custer CM, Read LB. Polychlorinated biphenyl congener patterns in tree swallows (Tachycineta bicolor) nesting in the Housatonic River watershed, western Massachusetts, USA, using a novel statistical approach. Environ Pollut 2006;142:235-45.

74. Maul JD, Belden JB, Schwab BA, Whiles MR, Spears B, Faris JL, Lydy MJ. Bioaccumulation and trophic transfer of polychlorinated biphenyls by aquatic and terrestrial insects to tree swallows (Tachycineta bicolor). Environ Toxicol Chem 2006;25:1017-25.

75. McKinney JD, Waller CL. Polychlorinated biphenyls as hormonally active structural analogues. Environ Health Persp 1994;102:290-7.

76. Institute for Environment and Health. Environmental oestrogens: consequences to human health and wildlife. Leicester, UK: IEH, University of Leicester; 1995.

77. Soto AM, Sonnenschein C, Chung KL, Fernandez MF, Olea N, Serrano FO. The E-SCREEN assay as a tool to identify estrogens: an update on estrogenic environmental pollutants. Environ Health Persp 1995;103:113-22.

78. Kelce WR, Stone CR, Laws SC, Gray LE, Kemppainen JA, Wilson EM. Persistent DDT metabolite p, p'-DDE is a potent androgen receptor antagonist. Nature 1995;375:581-5.

79. Cuomo V, De Salvia MA, Petruzzi S, Alleva E. Appropriate end points for the characterization of behavioral changes in developmental toxicology. Environ Health Perspect 1996;104:307-15.

80. Koolhaas JM, Meerlo P, De Boer SF, Strubbe JH, Bohus B. The temporal dynamics of the stress response. Neurosci Biobehav Rev 1997;21:775-82.

81. Sagerup K, Henriksen EO, Skorping A, Skaare JU, Gabrielsen GW. Intensity of parasitic nematodes increases with organochlorine levels in the glaucous gull. $J$ Appl Ecol 2000;7:532-9.

82. Sanderson JT, Elliott JE, Norstrom RJ, Whitehead PE, Hart LE, Cheng KM, Bellward GD. Monitoring biological effects of polychlorinated dibenzo-p-dioxins, dibenzofurans, and biphenyls in Great Blu Heron Chicks (Ardea herodias) in British Columbia. J Toxicol Environ Health 1994;41:435-50. 